Article

\title{
Herbicide Uptake and Regrowth Ability of Tall Fescue and Orchardgrass in S-Metolachlor-Contaminated Leachates from Sand Pot Experiment
}

\author{
Euro Pannacci * ${ }^{\mathbb{D}}$, Daniele Del Buono $\mathbb{D}$, Maria Luce Bartucca, Luigi Nasini, Primo Proietti $\mathbb{D}$ and \\ Francesco Tei \\ Department of Agricultural, Food and Environmental Sciences, University of Perugia, Borgo XX Giugno, \\ 74-06121 Perugia, Italy; daniele.delbuono@unipg.it (D.D.B.); marialucebartucca@gmail.com (M.L.B.); \\ agr.nasini@gmail.com (L.N.); primo.proietti@unipg.it (P.P.); francesco.tei@unipg.it (F.T.) \\ * Correspondence: euro.pannacci@unipg.it
}

Received: 7 September 2020; Accepted: 20 October 2020; Published: 21 October 2020

\begin{abstract}
The ability of tall fescue (Festuca arundinacea L.) and orchardgrass (Dactylis glomerata L.), to remediate leachates polluted with S-metolachlor (SMR) has been assessed in static hydroponic cultures. Different SMR concentrations $\left(0.25,1.00\right.$, and $\left.2.00 \mathrm{mg} \mathrm{L}^{-1}\right)$ were applied in the growth media to test the capacity of the two grasses to tolerate and uptake this herbicide, and to regrowth after mowing. S-metolachlor did not severely affect the dry weight aerial biomass of D. glomerata and F. arundinacea, which were reduced by $5 \%$ and $10 \%$, respectively, when compared to the untreated control, regardless of the SMR concentrations in the leachate. The regrowth ability of aerial biomass after mowing was reduced at the different SMR concentrations, according to a dose-response model. The SMR concentrations, which reduced the regrowth ability of F. arundinacea and D. glomerata of $10 \%$ and $30 \%$, were found to be $\mathrm{EC}_{10}$ (Effective Concentration) of 0.21 and $0.38 \mathrm{mg} \mathrm{L}^{-1}$ and $\mathrm{EC}_{30}$ of 0.45 and $0.74 \mathrm{mg} \mathrm{L}^{-1}$, respectively. These values could be assumed as the SMR concentrations that were well tolerated by both the species, without compromising their aerial biomass regrowth. Finally, tall fescue was found to be more effective and faster than orchardgrass in decreasing the SMR in the leachate and, therefore, this species should be preferred to be used in the vegetative buffer strips (VBS).
\end{abstract}

Keywords: herbicide pollution; phytoremediation; Festuca arundinacea L.; Dactylis glomerata L.; S-metolachlor; vegetative buffer strips

\section{Introduction}

Due to the continuous evolution of weed resistance to herbicides, growers are forced to introduce a range of different tactics to control weeds. A strategy that has rapidly increased in recent years is the use of pre-emergence herbicide [1,2]. Pre-emergence herbicide present a number of positive characteristics: (i) offer an alternative mode of action to many post-emergence herbicide; (ii) can reduce selection pressure on subsequent post-emergence herbicide applications; (iii) remove much of the early season weed competitive pressure on a crop and can protect yield better than post-emergence; (iv) are useful in crops where there is a lack of post-emergence options [1,3,4]. However, besides the harmful residual effect, it is also necessary to consider the environmental problems caused by the leaching of herbicides into deeper layers in the soil profile, which can reach underground aquifers [5].

Among the pre-emergence herbicides which have a high potential for soil contamination, there is the S-metolachlor (SMR) (IUPAC Name 2-Chloro-N-(2-ethyl-6-methylphenyl)-N-[(1S)2-methoxy-1-methylethyl]acetamide). The active compound is the stereoisomer $S$ of metolachlor 
(2-chloro-N-(6-ethyl-o-tolyl)-N-((1RS)-2-methoxy-1-methylethyl) acetamide), one of the most well-known and frequently used herbicides in Europe and the USA [6]. S-metolachlor is a chloroacetanilide, which acts by inhibiting the biosynthesis of long-chain fatty acids. This chemical is extensively used as a pre-emergence herbicide to control grasses and some broad-leaved weeds in a wide range of crops, such as corn, sugar beets, cotton, tomato, potato, tobacco, soybean and sunflower [6,7]. S-metolachlor has moderate to long persistence in soil and moderate persistence in water bodies. This property is the cause of its potential to contaminate surface and groundwater. For these reasons, this active compound is one of the five most frequently found herbicides in European freshwaters $[8,9]$. Furthermore, the effects of this active compound on non-target organisms have been reported in the literature [10-12].

Since environmental pollution has become an issue of great relevance, among all the techniques available to decontaminate polluted sites, phytoremediation technology is considered one of the most promising approaches [13]. This environment-friendly technology takes advantage of the capacity of some plants to tolerate high amounts of contaminants dispersed in polluted soils and/or water, and then to pick up and degrade them, thus remediating the contaminated matrices [13]. These species could also be used in the vegetative buffer strips (VBS), which have been proposed in recent years as a means to reduce surface water contamination caused by agricultural non-point pollution [14-16]. The VBS are riparian vegetated filter zones, interposed between fields and streams, which intercept and treat the waters leaving cropland [17]. The VBS allows reducing runoff flux, volume and herbicide concentration in the runoff water by increasing herbicide retention on organic matter and soil sediments [8]. In particular, S-metolachlor concentration in runoff water from a 6-m VBS was significantly reduced when compared to a non-VBS area at the first rainfall event after the herbicide application [15]. In addition, 3-m long grass VBS resulted in 77\% less runoff when simulated rainfall was applied 14 days after herbicide application [18]. However, before inferring the phytoremediation capacity of a certain species, it is first necessary to demonstrate its tolerance to xenobiotics. In particular, the selection of plant species for the phytoremediation of herbicides presents limitations when compared to programs aimed at the remediation of other contaminants. This is due to the molecular diversity and complexity of these compounds. Nonetheless, more recent studies addressed the question of whether herbaceous non-food plant species can decontaminate soils polluted with organic compounds and particularly herbicides [19].

To be effective in reducing pollution caused by herbicides, plants have to be able to uptake and act on the herbicide, which, however, should be bio-available. Therefore, the ideal plant for populating VBS for phytoremediation programs should be characterized by fast growth, high biomass, competitiveness and tolerance to herbicides $[13,19]$. In addition, plants should be capable to uptake, translocate and accumulate the herbicides in the harvestable tissues, and actuate their degradation. Finally, these species should not suffer from irreversible damages which could hinder their capacity to regrowth after mowing, guaranteeing their persistence in the VBS, as well as the herbaceous perennial species.

Festuca arundinacea L. (tall fescue) and Dactylis glomerata L. (orchardgrass) are very diffused cool season perennial grass species native to Europe. These perennial grasses offer some major advantages for phytoremediation strategies: (i) greater biomass production and extensive fibrous root systems; (ii) regrowth ability after mowing that allows an increase in the uptake and detoxification of herbicides and a more effective remedial action; (iii) long-lived species that increase their persistence in the buffer strips [20]. In addition, they have been successfully used for the phytoremediation of polluted soils and ground waters $[19,21]$, although data on the ability of these grass species to remediate water polluted with S-metolachlor are not available.

The scope of this research was to evaluate the possibility of using F. arundinacea (tall fescue) and D. glomerata (orchardgrass) in the remediation of soil polluted with SMR by measuring the effects of SMR on the plants aerial and root biomass, on their regrowth after mowing, and the residual amounts of the herbicide in time, in the plant growth mediums. 


\section{Materials and Methods}

\subsection{Plant Material and Growth Conditions}

Glasshouse trial was carried out maintaining the air temperature between $15^{\circ} \mathrm{C}$ and $30{ }^{\circ} \mathrm{C}$ and using F. arundinacea and D. glomerata in the static hydroponic cultures according to the methodology already described by Del Buono et al. [19]. Plastic pots ( $250 \mathrm{~mm}$ dia., model Verve Plus 1125B, Nicoli s.r.l, Vicenza, Italy; see for more details: https://www.nicoli.com/it/verve-plus.html), equipped with a water reservoir under the substrate and a water level indicator pipe, were filled with $6000 \mathrm{~g}$ of quartz sand (0.2-2 mm mesh size, $1.24 \mathrm{~g} \mathrm{~mL}^{-1}$ bulk density and $382 \mathrm{~mL} \mathrm{~L}^{-1}$ maximum water holding capacity) and sown with F. arundinacea and D. glomerata at the seeding rate of $1.26 \mathrm{~g} \mathrm{pot}^{-1}$ and $0.87 \mathrm{~g} \mathrm{pot}^{-1}$, respectively, which corresponds to 11,000 germinable seeds $\mathrm{m}^{-2}$. Pots were irrigated with $2850 \mathrm{~mL}$ of water, which was needed to obtain the maximum water holding capacity of the substrate $(1850 \mathrm{~mL})$ and fill the water reservoir $(1000 \mathrm{~mL})$ under the substrate. Pots were kept in the glasshouse arranged according to a completely randomized design with four replications. Water content was daily restored to the initial conditions $(2850 \mathrm{~mL})$, weighting each pot and adding the missing water, through the water level indicator pipe, in the water reservoir. Through the pipe, SMRs were also added for the treatments and we collected the leachate samples for SMR residue determination (see below). After emergence, all the necessary macro and micro-elements were added by applying once a week, for three weeks, 500 $\mathrm{mL}$ per pot of a nutrient solution (Flory $9^{\circledR}$, Agrimport s.p.a., Bolzano, Italy; $1 \mathrm{~g}$ c.f. $\mathrm{L}^{-1}+$ urea $0.1 \mathrm{~g}$ c.f. $\mathrm{L}^{-1}+$ Sequestrene ${ }^{\circledR} \mathrm{NK} 138 \mathrm{Fe}$, Ciba-Geigy Ltd., Basle, Switzerland; 0.04 g c.f. L ${ }^{-1}$ ).

Six weeks after emergence, at the tillering stage of plants, treatments with SMR were applied. For each species, different aliquots of a stock solution of SMR $\left(71.25 \mathrm{mg} \mathrm{L}^{-1}\right)$ were added to the pots, through the water level indicator pipe, directly in the water reservoir under the substrate, using a pipette. Then the pots were agitated in circle in order to mix homogeneously the aliquots in the water reservoir, obtaining a range of three SMR concentrations $\left(0.25,1.00\right.$, and $\left.2.00 \mathrm{mg} \mathrm{L}^{-1}\right)$. Four untreated pots for each species were considered as control. Very high SMR concentrations were chosen in order to test the plants' ability to resist extreme conditions of contamination.

For the determination of SMR residues, only the two higher dosages $\left(1\right.$ and $\left.2 \mathrm{mg} \mathrm{L}^{-1}\right)$ were considered, in three replicates. Samples of the leachates were collected by a pipette $(1 \mathrm{~mL})$, through the pipe, in the water reservoir under the substrate, at 1, 2, 3, 6, 9 and 14 days after the treatments (DAT), and immediately analyzed by HPLC as described in the following section.

Plants were mowed at $40 \mathrm{~mm}$ height above ground at $36 \mathrm{DAT}$, and the fresh and dry weights of aerial biomass per pot were recorded. Regrowth aerial biomass per pot was recorded at 87 DAT by mowing again at $40 \mathrm{~mm}$ height above ground, and by measuring the fresh and dry weights. Furthermore, each pot was immersed in water, the pot was removed, and the root system was repeatedly shaken manually, maintaining immersion, in order to remove the quartz sand by the roots without damaging them. The washed root systems were dried to $105^{\circ} \mathrm{C}$ for $48 \mathrm{~h}$ and weighted to determine dry root biomass.

\subsection{SMR Residues (HPLC)}

The SMR residues in the leachates were estimated by HPLC (Series 200, Perkin Elmer-Waltham, MA, USA), equipped with a detector LC-235 (Perkin Elmer-Waltham, MA, USA). The data were acquired and reprocessed by Chromera Software (Perkin Elmer-Waltham, MA, USA). The chromatographic separation was performed by using a C-18 RP column (Grace Alltima- $25 \mathrm{~cm}$ length, $4.6 \mathrm{~mm}$ i.d., $5 \mu \mathrm{m}$ mean particle size; Alltech Associates, Inc., Deerfield, IL, USA) in accordance with Mimmo et al. [22]. Briefly, the column was maintained at room temperature $\left(22^{\circ} \mathrm{C}\right)$, and the loop volume for the injections was set at $30 \mu \mathrm{L}$. The mobile phase was as follows: solvent A: water; solvent B: acetonitrile. The following gradient was applied: 2 min $95 \% \mathrm{~A}$ and $5 \% \mathrm{~B}$, followed by a linear increase in $5 \mathrm{~min}$ until $100 \% \mathrm{~B}$. The column was then maintained in this condition for $5 \mathrm{~min}$, after that it was set to the initial conditions for $5 \mathrm{~min}$, and left to re-equilibrate for another $5 \mathrm{~min}$. Under 
these chromatographic conditions, at the wavelength of $210 \mathrm{~nm}$ and the flow rate of $1.0 \mathrm{~mL} \mathrm{~min}{ }^{-1}$, the retention time of SMR was $13.7 \pm 0.05 \mathrm{~min}[22]$.

\subsection{Statistical Analysis}

Within each species, data of dry weight of herbicide treated and untreated plants were subjected to non-linear regression analyses using a logistic dose-response model [23]. This analysis permitted us to obtain the SMR concentrations required to cause reductions of $10,30,50$ and $90 \%$ of plant biomass $\left(\mathrm{EC}_{10}\right.$, $\mathrm{EC}_{30}, \mathrm{EC}_{50}$ and $\mathrm{EC}_{90}$, effective concentration) [24]. The assumption that the logistic dose-response curves could be fitted to the data was assessed by an F-test for lack-of-fit comparing the residual sum of squares of an analysis of variance and the non-linear regression [25]. The logistic dose-response model was fitted to the experimental data using the EXCEL ${ }^{\circledR}$ Add-in macro BIOASSAY97 [26]. For the SMR residue determinations, each reported value represents the mean \pm confidence interval $(p=0.05$, $n=9$ ) of data from three samples (replicates) and three determinations (pseudo-replicates) per sample.

\section{Results and Discussion}

\subsection{Effects on Plants and ECs Determination}

Dose-response curves of dry plant aerial biomass under different SMR concentrations showed that the herbicide did not severely affect the plant growth of both grass species at 36 DAT (Figure 1).

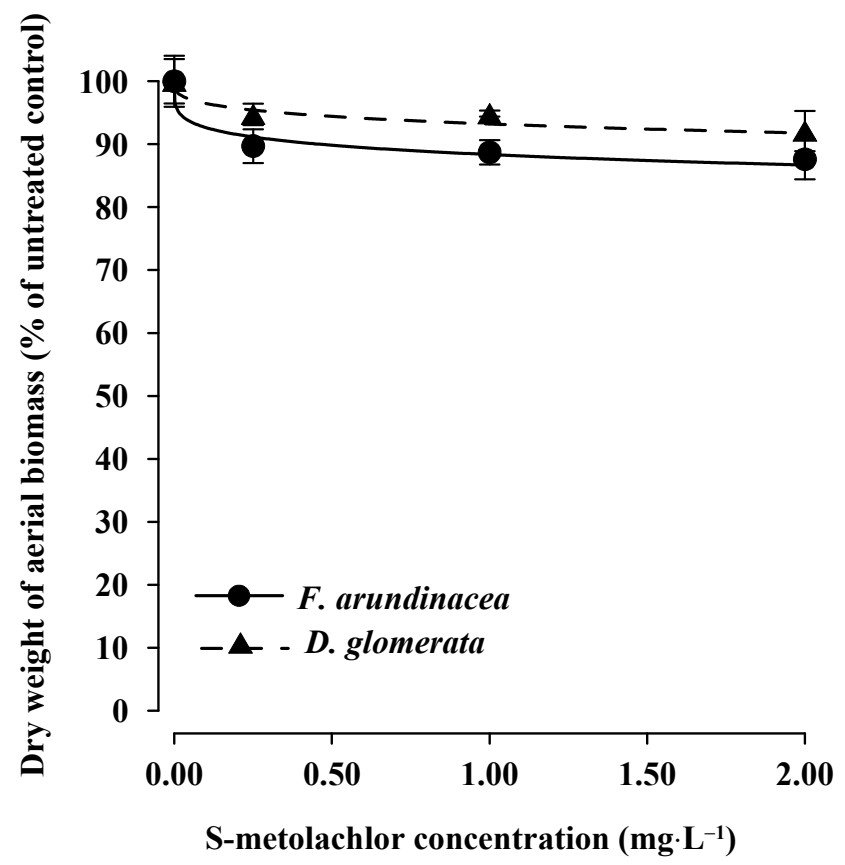

Figure 1. Effects of S-metolachlor (SMR) concentrations on dry weight aerial biomass of $F$. arundinacea (tall fescue) and D. glomerata (orchardgrass) at 36 DAT (days after treatments). The symbols indicate the observed data, the lines show the fitted curves according to a logistic dose-response model. Vertical bars represent \pm standard error.

Consequently, the parameters of dose-response curves were not significantly estimated, and so also $\mathrm{EC}_{10}, \mathrm{EC}_{30}, \mathrm{EC}_{50}$ and $\mathrm{EC}_{90}$ values were not estimated. These results showed that both $F$. arundinacea (tall fescue) and D. glomerata (orchardgrass) were tolerant to the phytotoxic effects of SMR when applied at the tillering growth stage, and this is evident also at the highest rate $\left(2 \mathrm{mg} \mathrm{L}^{-1}\right)$. Data regarding dry weight of aerial biomass of the treated plants indicated a great capacity of both grasses to grow in SMR-contaminated solutions. Small reductions in the aerial biomass were found for the two species which, compared to the untreated control, were about $5 \%$ for D. glomerata and $10 \%$ for $F$. arundinacea, 
regardless of the SMR concentrations (Figure 1). The dry weight reductions observed for the two species are a probable consequence of the SMR mode of action (growth inhibitors). Indeed, this herbicide acts by targeting the long-chain fatty acid (site of action group 15), causing both cell division and enlargement inhibition [27]. However, the primary site of action of this herbicide is still uncertain and strictly dependent on plant species. Furthermore, in graminaceous crops, metolachlor can also cause oxidative stress and decrease plant biomass production [28].

The regrowth ability of the two species, after the mowing at 36 DAT and under different SMR concentrations, was observed at 87 DAT (Figure 2).

Table 1. $\mathrm{EC}_{10}, \mathrm{EC}_{30}, \mathrm{EC}_{50}$, and $\mathrm{EC}_{90}$ (effective concentration) values ( $\mathrm{mg} \mathrm{L}^{-1}$ ) estimated from dose response curves of aerial biomass of regrowth of F. arundinacea (tall fescue) and D. glomerata (orchardgrass) treated with different S-metolachlor (SMR) concentrations (Figure 2). Regrowth was measured at 87 days after treatment (DAT) after the mowing at 36 DAT. Standard errors are in parenthesis.

\begin{tabular}{ccccc}
\hline Species & $\mathbf{E C}_{\mathbf{1 0}}$ & $\mathbf{E C}_{\mathbf{3 0}}$ & $\mathbf{E C}_{\mathbf{5 0}}$ & $\mathbf{E C}_{\mathbf{9 0}}$ \\
\hline F. arundinacea & $0.21(0.030)$ & $0.45(0.039)$ & $0.74(0.044)$ & $2.63(0.291)$ \\
D. glomerata & $0.38(0.205)$ & $0.74(0.209)$ & $1.13(0.201)$ & $3.37(1.583)$ \\
\hline
\end{tabular}

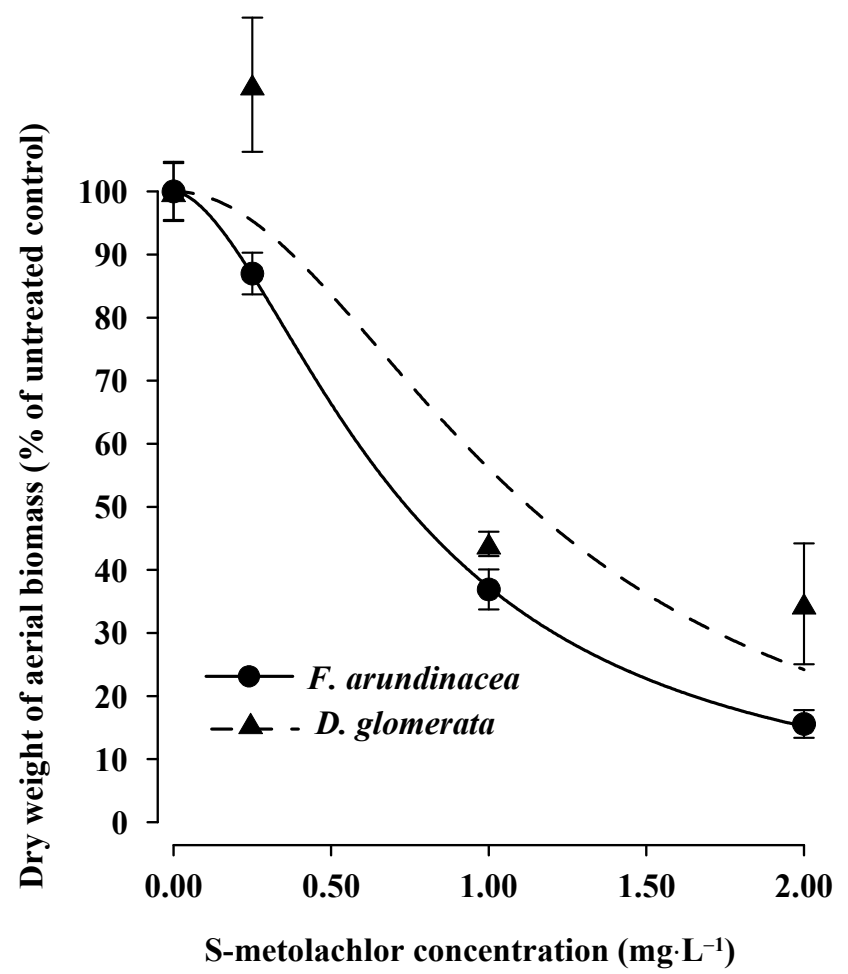

Figure 2. Effects of S-metolachlor (SMR) concentrations on regrowth of dry weight aerial biomass of F. arundinacea (tall fescue) and D. glomerata (orchardgrass) at 87 DAT (after the mowing of aerial biomass at 36 DAT). The symbols indicate the observed data, the lines show the fitted curves according to a logistic dose-response model (estimated effective concentrations are reported in Table 1). Vertical bars represent \pm standard error.

Dose-response curves showed that the dry weight aerial biomass of both species decreased when compared to the untreated control, especially at the two highest rates of SMR ( 1 and $2 \mathrm{mg} \mathrm{L}^{-1}$ ) (Figure 2). Dose-response curves were used to estimate the $\mathrm{EC}$ values (Table 1). Data regarding $\mathrm{EC}_{10}$, $\mathrm{EC}_{30}, \mathrm{EC}_{50}$, and $\mathrm{EC}_{90}$ indicated the concentrations of SMR capable of inhibiting plant regrowth after mowing. In particular, $\mathrm{EC}_{10}$ of 0.21 and $0.38 \mathrm{mg} \mathrm{L}^{-1}$ and $\mathrm{EC}_{30}$ of 0.45 and $0.74 \mathrm{mg} \mathrm{L}^{-1}$ were the SMR concentrations in the growth media capable of suppressing by $10 \%$ and $30 \%$, the regrowth ability of F. arundinacea and D. glomerata, respectively (Table 1). 
These values could be assumed as the SMR concentrations that were well tolerated by both grass species without compromising their regrowth ability, thus guaranteeing their efficacy in the mitigation of SMR in the VBS. On the other hand, the $\mathrm{EC}_{50}$ values $\left(0.74\right.$ and $1.13 \mathrm{mg} \mathrm{L}^{-1}$, respectively) should be considered as the maximum SMR concentrations tolerated by the two grass species, as they cause $50 \%$ of the reduction in the regrowth of aerial biomass.

In addition, these values should not be exceeded in order to maintain a satisfactory regrowth ability and, consequently, the possibility to persist, as herbaceous perennial species, in the VBS to mitigate the loss of SMR. Finally, the $\mathrm{EC}_{90}$ values of SMR (2.63 and $3.37 \mathrm{mg} \mathrm{L}^{-1}$, respectively) can irreversibly compromise the persistence of these species in the VBS, as they cause $90 \%$ reductions in the regrowth ability. However, based on these finding, it can be concluded that both the species can easily tolerate the SMR concentration in the runoff water. Otto et al. [29] found in a field experiment with silty-clay soil, under various types of rainfall, very lower SMR values $\left(0.77 \mu \mathrm{g} \mathrm{L}^{-1}\right)$ than $\mathrm{EC}_{10}$ and $\mathrm{EC}_{30}$ values. In fact, the SMR concentrations used in this research were very high and chosen in order to test the plants' ability to resist very extreme conditions of contamination, higher than those typically found in field experiments on the runoff and mitigations of SMR and other herbicides [15,30].

S-metolachlor did not affect the dry weight of root biomass in both species at 87 DAT (Figure 3) and, consequently, the parameters of dose-response curves, as well as the EC values, were not significantly estimated.

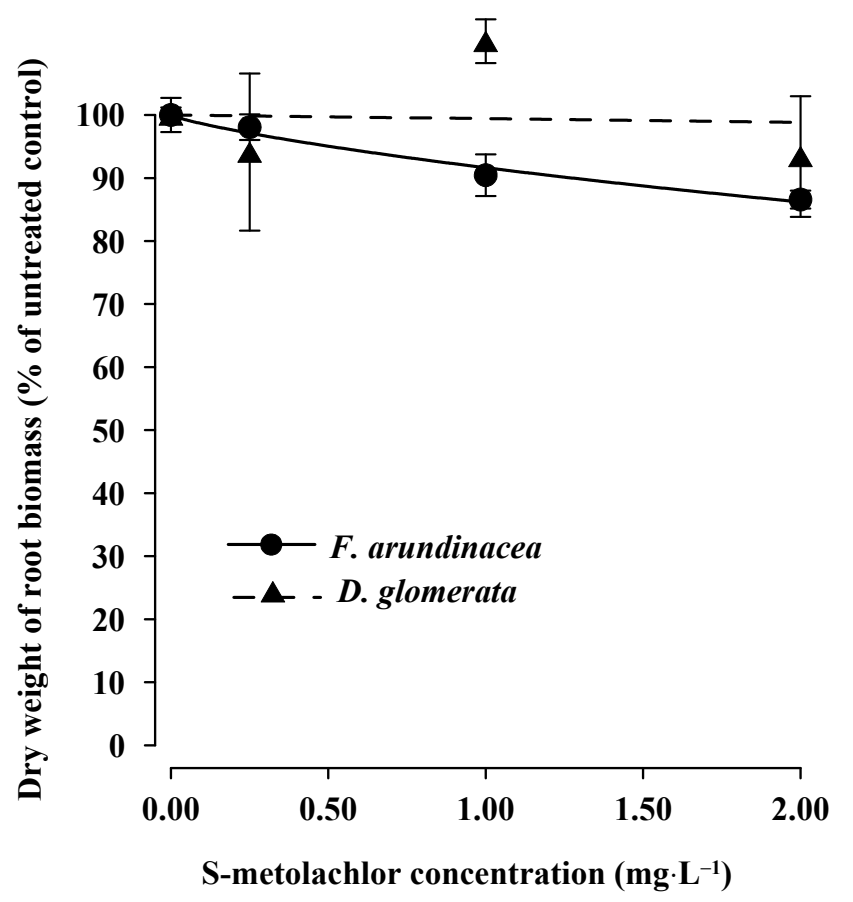

Figure 3. Effects of S-metolachlor (SMR) concentrations on dry weight root biomass of F. arundinacea (tall fescue) and D. glomerata (orchardgrass) at 87 DAT. The symbols indicate the observed data, the lines show the fitted curves according to a logistic dose-response model. Vertical bars represent \pm standard error.

These results are in line with those found for the aerial biomass, confirming the high tolerance of the two grass species to high SMR concentrations in the polluted water. No reduction in aerial and root growth of both species under different SMR concentrations means a good ability of these grass species to remediate polluted water without suffering damages. For this reason, these species may be considered very suitable to vegetate in the VBS for the herbicide mitigation. 


\subsection{SMR Residues in Plant Growth Water Mediums}

Water samples were collected from the growth media at different times after SMR treatments and the herbicide residues were determined by HPLC. The two highest SMR concentrations were considered (1 and $\left.2 \mathrm{mg} \mathrm{L}^{-1}\right)$.

F. arundinacea (tall fescue) was found to be effective in removing most of the concentrations of SMR added to the growth medium over 14 days (Figure 4 ).

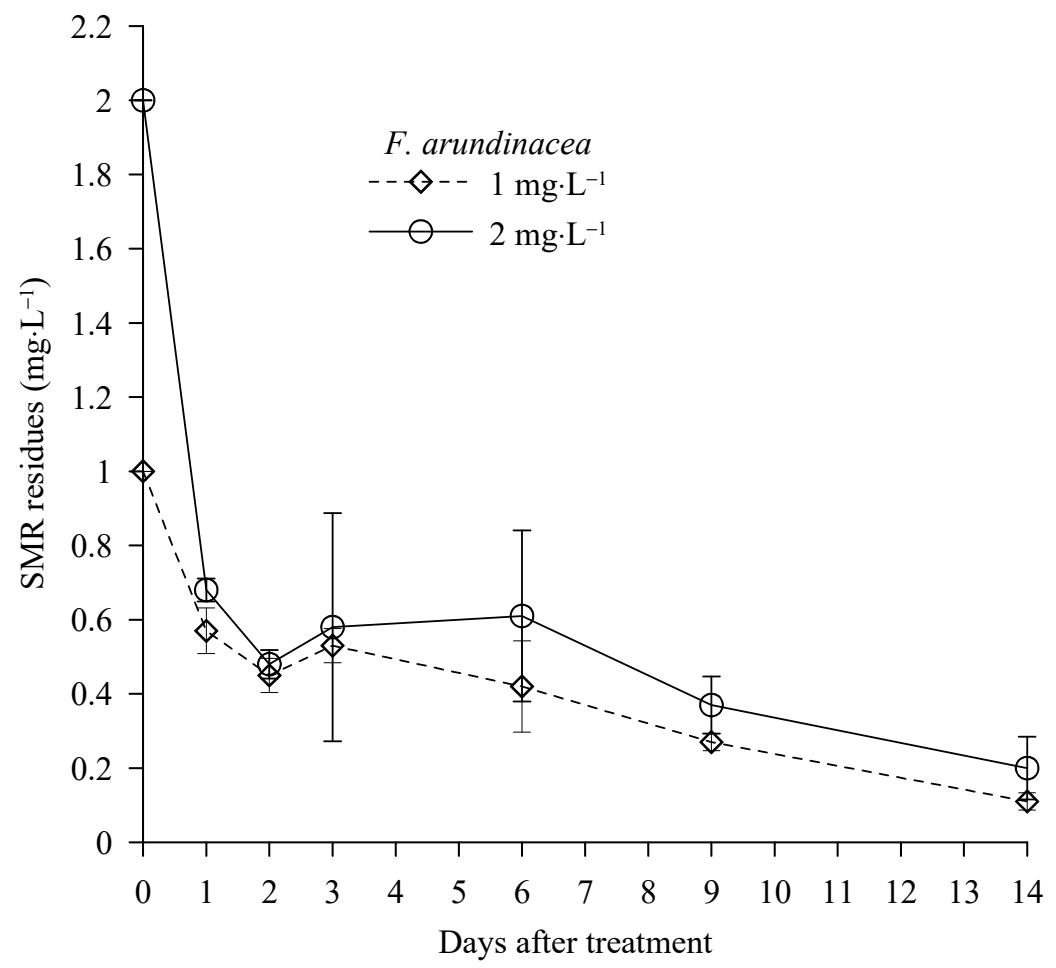

Figure 4. S-metolachlor (SMR) residues $\left(\mathrm{mg} \mathrm{L}^{-1}\right)$ determined in the growth media of F. arundinacea (tall fescue) at 1, 2, 3, 6, 9, 14 days after treatments (DAT) with 1 and $2 \mathrm{mg} \mathrm{L}^{-1}$ SMR concentrations. Vertical bars represent \pm confidence intervals $(p=0.05, n=9)$.

In particular, the plants were capable of removing most of the chemical within 1 DAT, and the quantity of SMR in the aqueous solutions was reduced until about $0.6 \mathrm{mg} \mathrm{L}^{-1}$, regardless of the dosage applied (Figure 4). In this case, the percentages of SMR removed from the leachates were $70 \%$ and $40 \%$ for the highest and lowest initial rates, respectively. After 1 DAT, the SMR remained relatively constant until 6 DAT. Thereafter, tall fescue was able to complete the SMR removal from the growth media almost entirely for all the dosages applied, over the experimental period (Figure 4).

In the case of $D$. glomerata (orchardgrass), the SMR removal from the growth medium was not completed for both the dosages $\left(1\right.$ and $\left.2 \mathrm{mg} \mathrm{L}^{-1}\right)$ (Figure 5). In particular, at the highest rate $\left(2 \mathrm{mg} \mathrm{L}^{-1}\right)$ the plants were able to reduce the quantity of SMR to $1 \mathrm{mg} \mathrm{L}^{-1}$ within $6 \mathrm{DAT}$, maintaining the SMR values steady at $1.7 \mathrm{mg} \mathrm{L}^{-1}$ from 1 to 3 DAT (Figure 5). From 6 to 14 DAT, SMR residues did not decrease significantly (Figure 5), therefore the percentages of SMR removed from the leachates were about $50 \%$ over the experimental period. At the rate of $1 \mathrm{mg} \mathrm{L}^{-1}$, the plants were unable to decrease the SMR residues until 9 DAT. After this period, the SMR decreased significantly at $0.7 \mathrm{mg} \mathrm{L}^{-1}$ at $14 \mathrm{DAT}$, with $30 \%$ of SMR removed from the leachates (Figure 5). 


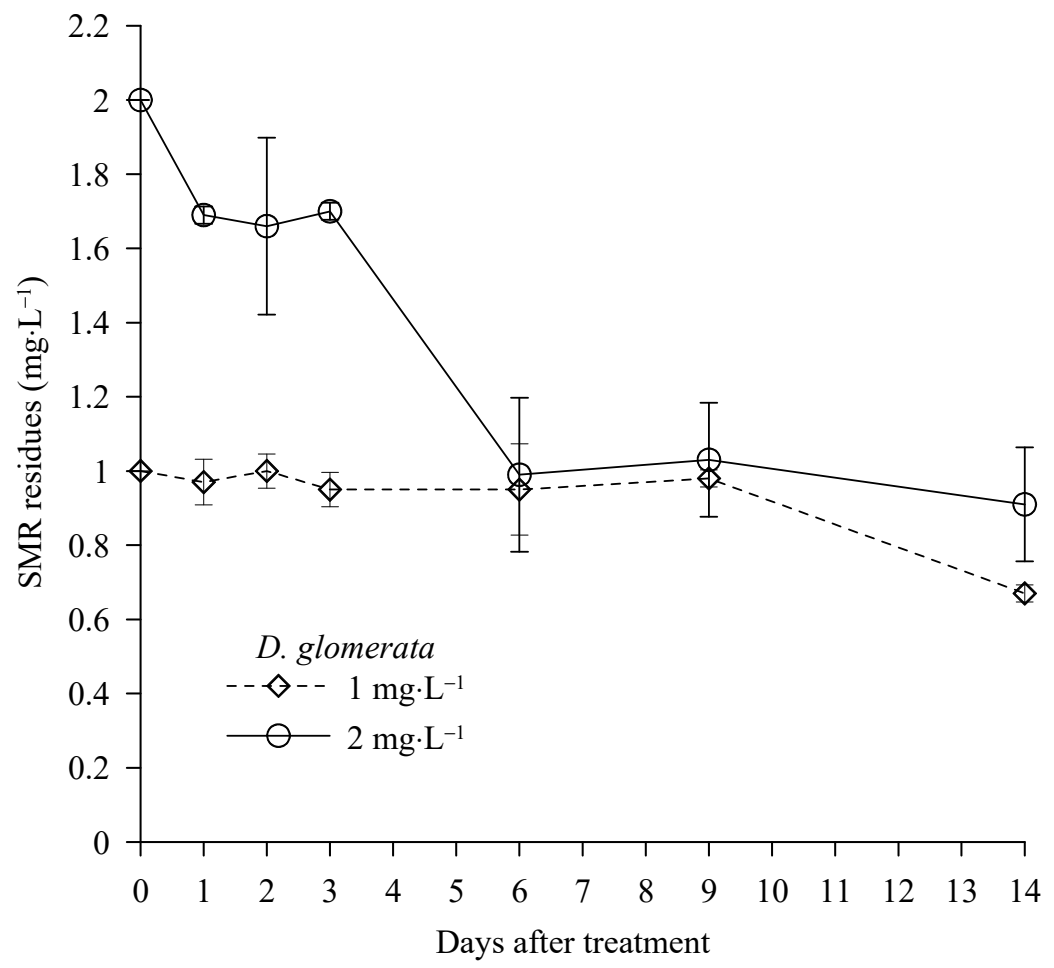

Figure 5. S-metolachlor (SMR) residues $\left(\mathrm{mg} \mathrm{L}^{-1}\right)$ determined in the growth media of D. glomerata (orchardgrass) at 1, 2, 3, 6, 9, 14 days after treatments (DAT) with 1 and $2 \mathrm{mg} \mathrm{L}^{-1}$ SMR concentrations. Vertical bars represent \pm confidence intervals $(p=0.05, n=9)$.

These findings clearly proved that F. arundinacea (tall fescue) was more effective and faster than D. glomerata (orchardgrass) in decreasing the SMR from the polluted water. Similar results were also obtained by Del Buono et al. [19], using these two species for the remediation of terbuthylazine. However, also D. glomerata reduced the SMR concentration in the water, although it needed two weeks to decrease by $50 \%$ the SMR concentration, showing a lower remediating ability than tall fescue. The rapidity in the uptake of SMR should be an important characteristic for selecting the species suitable for the VBS. Indeed, some researchers found low soil dissipation half-lives for SMR: between 7 and 16 days in a silty loam soil in Italy [15]; between 13 and 15 days in China [31]; between 19 and 21 days in Colorado [32]. In studies conducted in Europe on the behavior and fate of S-metolachlor in field conditions, the average half-life across different soil types was 23 days [33].

For the reasons above, both grasses could be suggested as herbaceous species to populate VBS for herbicides mitigation. However, tall fescue should be preferred for its effectiveness and fastness in water remediation, especially in sandy soils to quickly remove the SMR from surface runoff and infiltrated water before contaminating groundwater.

The differences between the two species in the ability to remove SMR from the growth media could be explained based on a more efficient antioxidant and detoxifying metabolism of $F$. arundinacea than D. glomerata. This characteristic was already observed by Del Buono et al. [19] for these two species used in this study, to remediate water polluted by terbuthylazine. However, further investigations are needed to shed light on the antioxidant and detoxifying metabolism activated by these species when grown in soil water polluted with SMR.

\section{Conclusions}

The effects of SMR on regrowth ability and root biomass showed that both F. arundinacea (tall fescue) and D. glomerata (orchardgrass) were tolerant to high concentrations of this herbicide in the leachates from contaminated sand. The survival of both grass species was not compromised even at the highest SMR concentration which was much higher than those normally found in field experiments on SMR 
runoff and mitigations. Both species were showed to be able to reduce SMR in the polluted water, although with differences in terms of quantity and time. F. arundinacea was found to be more effective and faster than D. glomerata in decreasing the SMR in the polluted water and, therefore, this species should be preferred to vegetate the VBS.

Further investigations are required to understand the antioxidant and detoxifying metabolism involved in these species' growths in polluted water with SMR, and to evaluate the performances of the grass species in field conditions. In fact, the plant's capacity to resist the herbicides, and then to clean up polluted environments, also depends on its ability to overcome deleterious effects due to herbicide action, mainly oxidative stress. These chemicals often give rise to the overproduction of reactive oxygen species (ROS), which can impair the antioxidant defenses and kill the species. Among the antioxidant enzymes involved in facing ROS, ascorbate peroxidases (APX), which catalyze the removal of $\mathrm{H}_{2} \mathrm{O}_{2}$ by using ascorbic acid as a specific electron donor, are well known for their important role.

Author Contributions: Conceptualization, E.P., D.D.B. and M.L.B.; data curation, E.P., D.D.B. and M.L.B.; formal analysis, E.P., D.D.B. and M.L.B.; methodology, E.P., D.D.B. and M.L.B.; writing-original draft preparation, E.P.; writing-review and editing, E.P., D.D.B., M.L.B., L.N., P.P. and F.T.; funding acquisition, D.D.B., L.N. and P.P.; project administration, D.D.B., L.N., P.P. and F.T.; supervision, D.D.B., P.P. and F.T. All authors have read and agreed to the published version of the manuscript.

Funding: This research was funded by the Italian Ministry of Education, Universities and Research (FIRB - Programma "Futuro in Ricerca" 2012-RBFR127WJ9) and by the Italian project of the Umbria region on the buffer strips.

Acknowledgments: The authors would like to acknowledge Locchi Silvano (Dept. of Agricultural, Food and Environmental Sciences, University of Perugia) for technical assistance.

Conflicts of Interest: The authors declare no conflict of interest.

\section{References}

1. Congreve, M. Pre-Emergent Herbicides Fact Sheet. GRDC Update Paper, Australia. 2015. Available online: https://grdc.com.au/_data/assets/pdf_file/0025/126475/grdc_fs_pre-emergent-herbicides-pdf.pdf.pdf (accessed on 12 July 2020).

2. Pannacci, E.; Onofri, A. Alternatives to terbuthylazine for chemical weed control in maize. Commun. Biometry Crop Sci. 2016, 11, 51-63.

3. Beckie, H.J.; Ashworth, M.B.; Flower, K.C. Herbicide resistance management: Recent developments and trends. Plants 2019, 8, 161. [CrossRef] [PubMed]

4. Gage, K.L.; Krausz, R.F.; Walters, S.A. Emerging challenges for weed management in herbicide-resistant crops. Agriculture 2019, 9, 180. [CrossRef]

5. Del Buono, D.; Ioli, G.; Nasini, L.; Proietti, P. Comparative study on the interference of two herbicides in wheat and Italian ryegrass and on their antioxidant activities and detoxification rates. J. Agric. Food Chem. 2011, 59, 12109-12115. [CrossRef] [PubMed]

6. Gikas, G.D.; Vryzas, Z.; Tsihrintzis, V.A. S-metolachlor herbicide removal in pilot-scale horizontal subsurface flow constructed wetlands. Chem. Eng. J. 2018, 339, 108-116. [CrossRef]

7. Pannacci, E.; Graziani, F.; Covarelli, G. Use of herbicide mixtures for pre and post-emergence weed control in sunflower (Helianthus annuus). Crop Prot. 2007, 26, 1150-1157. [CrossRef]

8. Zemolin, C.R.; Avila, L.A.; Cassol, G.V.; Massey, J.H.; Camargo, E.R. Environmental fate of S-Metolachlor: A review. Planta Daninha 2014, 32, 655-664. [CrossRef]

9. PPDB (Pesticide Properties Data Base). S-metolachlor, General Information. University of Hertfordshire, UK. 2020. Available online: https://sitem.herts.ac.uk/aeru/ppdb/en/Reports/1027.htm (accessed on 17 June 2020).

10. Liu, H.; Xiong, M. Comparative toxicity of racemic metolachlor and S-MET to Chlorella pyrenoidosa. Aquat. Toxicol. 2009, 93, 100-106. [CrossRef]

11. Mathias, F.T.; Romano, R.M.; Sleiman, H.K.; de Oliverira, C.A.; Romano, M.A. Herbicide metolachlor causes changes in reproductive endocrinology of male wistar rats. ISRN Toxicol. 2012, 2012, 1-7. [CrossRef]

12. Joly, P.; Misson, B.; Perrière, F.; Bonnemoy, F.; Joly, M.; Donnadieu-Bernard, F.; Aguer, J.P.; Bohatier, J.; Mallet, C. Soil surface colonization by phototrophic indigenous organisms, in two contrasted soils treated by formulated maize herbicide mixtures. Ecotoxicology 2014, 23, 1648-1658. [CrossRef] 
13. Pilon-Smits, E. Phytoremediation. Ann. Rev. Plant Biol. 2005, 56, 15-39. [CrossRef] [PubMed]

14. Vianello, M.; Vischetti, C.; Scarponi, L.; Zanin, G. Herbicide losses in runoff events from a field with a low slope: Role of a vegetative filter strip. Chemosphere 2005, 61, 717-725. [CrossRef] [PubMed]

15. Milan, M.; Vidotto, F.; Piano, S.; Negre, M.; Ferrero, A. Buffer strip effect on terbuthylazine, desethyl-terbuthylazine and S-metolachlor runoff from maize fields in Northern Italy. Environ. Technol. 2013, 34, 71-80. [CrossRef] [PubMed]

16. Carretta, L.; Cardinali, A.; Zanin, G.; Masin, R. Effect of vegetative buffer strips on herbicide runoff from a nontilled soil. Soil Sci. 2017, 182, 285-291. [CrossRef]

17. Borin, M.; Passoni, M.; Thiene, M.; Tempesta, T. Multiple functions of buffer strips in farming areas. Eur. J. Agron. 2010, 32, 103-111. [CrossRef]

18. Pätzold, S.; Klein, C.; Brummer, G.W. Run-off transport of herbicides during natural and simulated rainfall and its reduction by vegetated filter strips. Soil Use Manag. 2007, 23, 294-305. [CrossRef]

19. Del Buono, D.; Pannacci, E.; Bartucca, M.L.; Nasini, L.; Primo Proietti, P.; Tei, F. Use of two grasses for the phytoremediation of aqueous solutions polluted with terbuthylazine. Int. J. Phytoremediat. 2016, 18, 885-891. [CrossRef]

20. Chekol, T.; Vough, L.R. Assessing the phytoremediation potential of tall fescue and sericea lespedeza for organic contaminants in soil. Remediat. J. 2002, 12, 117-128. [CrossRef]

21. Kim, Y.B.; Park, K.Y.; Chung, Y.; Oh, K.C.; Buchanan, B.B. Phytoremediation of anthracene contaminated soils by different plant species. J. Plant Biol. 2004, 47, 174-178. [CrossRef]

22. Mimmo, T.; Del Buono, D.; Terzano, R.; Tomasi, N.; Vigani, G.; Crecchio, C.; Pinton, P.; Zocchi, G.; Cesco, S. Rhizospheric organic compounds in the soil-microorganism-plant system: Their role in iron availability. Eur. J. Soil Sci. 2014, 65, 629-642. [CrossRef]

23. Streibig, J.C.; Rudemo, M.; Jensen, J.E. Dose-response curves and statistical models. In Herbicide Bioassay; Streibig, J.C., Kudsk, P., Eds.; CRC Press: Boca Raton, FL, USA, 1993; pp. $29-55$.

24. Copping, L.G.; Hewitt, H.G.; Rowe, R.R. Evaluation of a new herbicide. In Weed Control Handbook: Principles, 8th ed.; Hance, R.J., Holly, K., Eds.; Blackwell Scientific Publication: Oxford, UK, 1990; pp. 261-299.

25. Ritz, C.; Streibig, J.C. Bioassay Analysis Using R. J. Stat. Softw. 2005, 12, 1-22. [CrossRef]

26. Onofri, A.; Pannacci, E. Spreadsheet tools for biometry classes in crop science programmes. Commun. Biometry Crop Sci. 2014, 9, 3-13.

27. Böger, P.; Matthes, B. Inhibitors of Biosynthesis of Very-Long-Chain Fatty Acids. In Herbicide Classes in Development; Böger, P., Wakabayashi, K., Hirai, K., Eds.; Springer: Berlin/Heidelberg, Germany, 2002; pp. 117-137.

28. Panfili, I.; Bartucca, M.L.; Marrollo, G.; Povero, G.; Del Buono, D. Application of a plant biostimulant to improve maize (Zea mays) tolerance to metolachlor. J. Agric. Food Chem. 2019, 67, 12164-12171. [CrossRef] [PubMed]

29. Otto, S.; Cardinali, A.; Marotta, E.; Paradisi, C.; Zanin, G. Effect of vegetative filter strips on herbicide runoff under various types of rainfall. Chemosphere 2012, 88, 113-119. [CrossRef] [PubMed]

30. Otto, S.; Vianello, M.; Infantino, A.; Zanin, G.; Di Guardo, A. Effect of a full-grown vegetative filter strip on herbicide runoff: Maintaining of filter capacity over time. Chemosphere 2008, 71, 74-82. [CrossRef] [PubMed]

31. Cao, P.; Wang, X.; Liu, F.; Zhao, E.; Han, L. Dissipation and residue of S-metolachlor in maize and soil. Bull. Environ. Contam. Toxicol. 2008, 80, 391-394. [CrossRef] [PubMed]

32. Shaner, D.L.; Henry, W.B. Field history and dissipation of atrazine and metolachlor in Colorado. J. Environ. Qual. 2007, 36, 128-134. [CrossRef]

33. O'Connell, P.J.; Harms, C.T.; Allen, J.R.F. Metolachlor, S-metolachlor and their role within sustainable weed management. Crop Prot. 1998, 17, 207-212. [CrossRef]

Publisher's Note: MDPI stays neutral with regard to jurisdictional claims in published maps and institutional affiliations. 